\title{
Occupational therapy and eating disorders: an integrative literature review
}

\author{
Elysa Roberts ${ }^{1 *}$, William Wolfenden ${ }^{2}$ \\ From 2015 ANZAED Conference: Riding the Waves to Recovery \\ Surfers Paradise, Australia. 21-22 August 2015
}

\section{Introduction}

Literature pertaining to the role of occupational therapy in recovery from eating disorders spans 40 years; however, has not been systematically synthesized.

\section{Methods}

To develop a comprehensive understanding of reported roles of occupational therapy in recovery from eating disorders and inform intervention and research, we conducted an integrative literature review. Searches were conducted in ten online databases and six occupational therapy journals. Theoretical or empirical publications in peer-reviewed journals in English explicitly describing occupational therapy intervention or role of the occupational therapist for eating disorders were included. Thematic analysis was conducted across selected articles and research articles critically reviewed.

\section{Results}

Thirty-two pieces of evidence published in English from 1974 through 2014 were included in this review; twentyfour were theoretical and eight were qualitative, descriptive or quasi-experimental studies. Analysis revealed the domain and process of occupational therapy with persons with eating disorders. Results are represented as a conceptual model illustrating a variation of the American Occupational Therapy Association Practice Framework. Appraisal of the studies suggests a need and opportunity to document and disseminate the evidence-base for this practice area.

\section{Conclusion and significance}

Findings of this integrative literature review inform research, practice and clinical training of occupational therapists in the specialty area of eating disorder recovery.

\section{Authors' details}

'University of Newcastle, Newcastle, Australia. ${ }^{2}$ Bondi Junction Community Mental Health Centre, Sydney, Australia.

Published: 23 November 2015

doi:10.1186/2050-2974-3-S1-P8

Cite this article as: Roberts and Wolfenden: Occupational therapy and eating disorders: an integrative literature review. Journal of Eating Disorders 2015 3(Suppl 1):P8.
Submit your next manuscript to BioMed Central and take full advantage of:

- Convenient online submission

- Thorough peer review

- No space constraints or color figure charges

- Immediate publication on acceptance

- Inclusion in PubMed, CAS, Scopus and Google Scholar

- Research which is freely available for redistribution
C Biomed Central 